\title{
Effect of GA3 and Shading on the Growth and Content of Artemisinin Compound in Leaf of Artemisia (Artemisia annua L.) Grown on the Medium Land of Karanganyar, Indonesia
}

\author{
${ }^{1}$ Yuni Kusumodewi, ${ }^{2}$ Usman Siswanto, ${ }^{3}$ Samanhudi and ${ }^{3}$ Ahmad Yunus \\ ${ }^{1}$ Student of Graduate School of Agronomy, Universitas Sebelas Maret, Surakarta Indonesia \\ ${ }^{2}$ Faculty of Agriculture, Universitas Bengkulu, Bengkulu, Indonesia \\ ${ }^{3}$ Faculty of Agriculture, Universitas Sebelas Maret, Surakarta, Indonesia
}

Article history

Received: 21-12-2016

Revised: $20-05-2017$

Accepted: 18-10-2017

Corresponding Author: Ahmad Yunus

Faculty of Agriculture, Universitas Sebelas Maret, Surakarta, Indonesia Tel.: +62-271-637457 Email: yunus.uns7@yahoo.com

\begin{abstract}
Malaria is still becomes a concern for the government of Indonesia, since this disease has affected many people. Artemisia annua $\mathrm{L}$. is an aromatic plant that destroys malarial parasites, lowers fever and of which the secondary metabolite is artemisinin. Enhanced production of the artemisinin content in the whole plant is desirable. This experiment was conducted in Karanganyar, Indonesia $900 \mathrm{~m}$ asl. The purpose of this field experiment was to investigate the effects of GA3 and shading on the growth and content of artemisinin of Artemisia. Experiment using Completely Randomized Block Design (CRBD) arranged in factorial treatments. The first factor was the concentration of GA3 consists of 4 levels, namely: G0 (without GA3), G1 (50 ppm GA3), G2 (100 ppm GA3) and G3 (150 ppm GA3). The second factor was the level of shade, which consists of three levels, namely: N0 (without shade), N1 (55\% shade) and N2 (75\% shade). The results showed that: $100 \mathrm{ppm}$ GA3 increased plant dry weight, chlorophyll content and yield of total extract. A treatment without shade gives the best results on the height of plant, length of root, fresh weight of plant, dry weight of plant and yield of total extract. Treatment of $150 \mathrm{ppm}$ of GA3 and $75 \%$ shade gave the highest content of artemisinin (3.96\%) while control provided $0.64 \%$.
\end{abstract}

Keywords: Artemisia Annua, Artemisinin, GA3, Shade, Malaria

\section{Introduction}

Malaria is an infectious disease with high prevalence in Indonesia, as well as in several tropical countries in the world (Rogers and Randolp, 2000; Milliken, 1997; Mueller et al., 2000). According to the World Health Organization's estimation, millions of acute and chronic malaria infection, approximately $85 \%$ were caused by the malaria parasite; Plasmodium falciparum. In the development of Plasmodium falciparum, it became resistant to chloroquine in the early of sixties. This phenomenon encourages the need for development of new anti-malarial drugs. By the existence of parasite that has been resistant to these drugs, the experts looked for the other compounds or other synthetic drugs that derived from natural products, artemisinin from Artemisia aпnиa.

A. апnиa is an aromatic plant that can be used for the treatment of fever and malaria (Klayman et al.,
1985; Mukherjee, 1991). To increase the yield and quality of plant, among various ways using growthregulator substances and reduction of light intensity are the major one.

The isolated active compound have been identified as sesquiterpene lactone (Liu et al., 2001). It was isolated from Artemisia annua L. by Chinese scientists when searching for novel antimalarial drugs in the 1970s (Li et al., 2006). This substance is claimed as an antimalarial compound which is very effective and has no effects (Dhingra et al., 2000). The artemisinin content from A. апnиa is highly variable, ranging anywhere between 0.01 and $1 \%$, depending on variety and can even be as high as $1.4 \%$ in some cultivated strains (Brown, 2010).

Research on the extract of Artemisia showed that there is hepato-protective activity and this plant is traditionally used to cure liver disorders (Gilani et al., 2005). In oriental healing, it can be used for analgesia and 
acupuncture therapy (Judzentiene and Buzelyte, 2006). GA3 can improve the growth of Artemisia plant which can increase the dry weight of the Artemisia plant (Jehnsen, 2010).

The need of light is important to be concerned because the plants will give a response to the amount of received light. The high intensity of light causes the high temperature which can lead to a decrease in humidity and vice versa. To cope with unfavourable circumstances due to extreme environments, it can be done by providing shade.

However, when granting the shade, it should consider the intensity of the shade, because if the shade is too tight, it will cause inadequacy of light as source of energy for the metabolic activity of the plant that will impact to reduction of the results (Muhartini and Kurniasih, 2000).

Considering the enormous potential of giving shade as a source of malaria drugs, it is necessary to do the cultivation of plants which leads to the content growth of the active compound. For those reasons, the researcher will conduct a research on the effects of GA3 and shade levels to the content of artemisinin in A. annua plants.

\section{Materials and Methods}

The seeds of Artemisia annua were initially sown in the seedbeds to obtain seedlings. The seedling were transplanted into the experiment field. Experiment was carried out in Karanganyar, Central Java, Indonesia, with the altitude of $900 \mathrm{~m}$ above sea level, using Completely Randomized Block Design with factorial experimental application, consisting of two treatment factors. The first factor was GA3 concentration with four levels, which were: without GA3, GA3: 50 ppm, GA3: 100 ppm and GA3:150 ppm. The second factor was shade, namely: Without shade, 55 shade and $75 \%$ shade. Each treatment was replicated three times. The land area of $250 \mathrm{~m}^{2}$ was divided into three blocks, each of blocks was divided into 12 plots treatment. The distance of planting was $30 \mathrm{~cm} \times 40 \mathrm{~cm}$, the distance among the blocks was $50 \mathrm{~cm}$, the distance between plots was $30 \mathrm{~cm}$, the number of plant per plots were 25 plants. Before transplantation a uniform basal dose of $\mathrm{N}, \mathrm{P}$ and $\mathrm{K}$ applied at the rate of 80,40 and $40 \mathrm{~kg} \mathrm{ha}^{-1}$, respectively, to the field plots. The plants were sprayed with GA3 and in combination with shade treatment. There were 12 treatment combinations. The treatments consisted of: (1) GA3 0 ppm + no shade, (2) GA3 0 ppm + shade 55\%, (3) GA3 0 ppm + shade 75\%, (4) GA3 50 ppm + no shade, (5) GA3 $50 \mathrm{ppm}+$ shade 55\%, (6) GA3 $50 \mathrm{ppm}$ + shade 75\%, (7) GA3 $100 \mathrm{ppm}+$ no shade, (8) GA3
$100 \mathrm{ppm}+$ shade 55\%, (9) GA3 $100 \mathrm{ppm}+$ shade $75 \%$, (10) GA3 $150 \mathrm{ppm}+$ no shade, (11) GA3 150 ppm + shade $55 \%$, (12) GA3 150 ppm + shade $75 \%$.

The maintenance was primarily conducted on watering and weeding. The observation was conducted on the height of plants, the length of roots, the content of chlorophyll, the plant fresh weight, the plant dry weight, the total extract of yield, as well as the content of artemisinin. Plants were sampled at 100 DAP.

\section{Estimation of Total Chlorophyll Content}

Total Chlorophyll content in fresh leaves. One hundred mg of fresh tissue from leaf areas was ground using a mortar and pestle containing $80 \%$ acetone. The optical density of the solution was recorded using a spectrophotometer (Shimadzu UV 1700, Japan).

\section{Yield Extract Total}

Simplicia was powdered and extracted by percolation method (Dhingra et al., 2000). Liquid extract was evaporated on water bath until dried. Weigh the cup before and after added dried extract. Weigh dried extract. The yield of extract was calculated based on the formula.

The yield of extract:

$$
(R)=\frac{(b-a)}{c} \times 100 \%
$$

With:

$a=$ Weight of empty cup

$b=$ Weight of cup + weight of dried extract

$c=$ Weight of extracted simplicia powder

\section{Artemisinin Content}

Artemisinin content was analysed by hexane extraction method (Tang et al., 2000). Dried leaves was powdered, then extracted with hexane in sochlet for $48 \mathrm{~h}$ and evaporated. Residue of hexane was diluted in hexane for overnight and filtered. Hexane solution was partitioned with $20 \% \mathrm{MeCN}$ solution and evaporated. $20 \%$ of $\mathrm{MeCN}$ was cleaned with $10 \%$ of its volume with hexane, added of 7 gram $\mathrm{NaCl}$ in 100 $\mathrm{mL} \mathrm{MeCN}$ solution and evaporated. Residue of $\mathrm{MeCN}$ was eluationed by $10-20 \%$ of hexane.

\section{Statistical Analysis}

Each plot was treated as one replicate and all the treatments were replicated three times. The means of the data was analysed statistically using SPSS-17 statistical software (SPSS Inc., Chicago, IL, USA). Mean values were statistically compared by Duncan's Multiple Range Test (DMRT) at $\mathrm{p} \rrbracket 0.05$ level using different letters. 


\section{Results and Discussion}

\section{Yield of Total Extract}

According to analysis of variance, there is significant interaction was registered for total extract between GA3 and shade treatment. Areas of light intensity significantly affect the yield of total extract. The yield of total extract looked better in the open place with high light intensity. The highest yield $(21.25 \%)$ for yield of total extract was derived from $100 \mathrm{ppm}$ of GA3 treatment and without shade, while the lowest yield (15.54\%) of total extract was derived from without GA3 and $75 \%$ shade treatment (Table 1). It can be explained that the rate of photosynthesis arose during the light intensity also arise too.

\section{Levels of artemisinin}

The result of variance analysis showed that there is interaction between GA3 treatment and the level of shade on artemisinin content. The highest level of artemisinin was obtained for $150 \mathrm{ppm} \mathrm{GA3}$ and $75 \%$ shade treatment (Table 2). It is probably that the increased levels of artemisinin due to Artemisia obtain sufficient substrate for biosynthesis of artemisinin, precursor of artemisinin biosynthesis is Farnesyl Diphosphate (FPP) (Liu et al., 2011), while precursor of Gibberellin biosynthesis is geranyl geranyl diphosphate (GGPP) (Hedden and Proebsting, 1999), those precursors are derived from Dimethylallyl Diphosphate (DMAPP) (Liu et al., 2011), therefore, plant tend to synthesis artemisinin. The plants also get enough light intensity, so that the intensity of light which is used to biosynthesis artemisinin will be optimal and it will be accumulated on leaves, flowers and roots.

\section{Height of Plant}

The result of analysis of variance showed that GA3 treatment and the level of shade did not show a significantly different effect on the height of plant. The highest plant's height $(84.2 \mathrm{~cm})$ was obtained for 150 ppm GA3 treatment and no shade treatment ( 87.0 $\mathrm{cm})$ while the lowest $(69.9 \mathrm{~cm})$ was recorded for without GA3 Table 3. It can be explained that GA3 increased the growth of $A$. annua indicating that GA3 has an important role in the growth of artemisia. Thus, the increasing of GA3 concentration up to $150 \mathrm{ppm}$ was in line with the increasing of the plant's height. In fact, treatment without shade produced the highest plants, it was indicate that the need of light for plant's growth is really important, because it enables plant to carry out photosynthesis and produce metabolites that used for the plant's growth and development later (Fitter and Hay, 1998).

\section{Root Length}

GA3 and shade treatments showed insignificant difference for the length of roots. The longest roots was obtained for $150 \mathrm{ppm}$ GA3 while $55 \%$ was for shade treatment. Allegedly, by giving GA3 at higher concentrations, it can increase the length of roots.

In agreement with this Jehnsen (2010) states that, the use of GA3 on Artemisia plant will affect the grain dry weight and, the length of the roots. Shade treatment can impact the soil and the microclimate around the plant. Gardner et al. (1991), states that light can affect the soil environment and developmental differences rooting. Shade of $55 \%$ provide greater root length, it is possible that $55 \%$ shade can provide an appropriate micro climate and environment on the growth of the roots.

\section{Chlorophyll Content}

The content of leaf chlorophyll was measured when the age of plants reached 45 Days After Planting (DAP), 60 DAP and 75 DAP. The result of variance analysis showed that, various GA3 and shade levels gave significant effect on the content of leaf chlorophyll. There was no interaction between GA3 treatment and shade levels on the chlorophyll content. The highest chlorophyll content was obtained for 100 ppm GA3 treatment without shade and it was obtained when the age of plant reached 60 DAP with the average of chlorophyll content is 26.8 ; it possibly cause the decline on the addition of GA3 either on high or low concentration. It showed that $100 \mathrm{ppm}$ is an appropriate concentration for GA3 to increase the leaf chlorophyll content of $A$. апnиа (Table 3 ).

\section{Fresh Weight}

The analysis of variance proved that there was no significant difference among both treatments concerning plant fresh weight. The highest fresh weight was produced in the open place compared to other treatments; Contrary to this, the plant fresh weight tend to decrease under the higher levels of shade treatments.

Table 1. Effect of GA3 and shade on the yield level of total extract of $A$. апnua

\begin{tabular}{llll}
\hline & $(\%)$ & & \\
Treatment & N0 & N1 & N2 \\
\hline G0 & $17.44^{\mathrm{e}}$ & $19.33^{\mathrm{b}}$ & $15.54^{\mathrm{g}}$ \\
G1 & $17.46^{\mathrm{e}}$ & $18.17^{\mathrm{d}}$ & $17.48^{\mathrm{e}}$ \\
G2 & $21.25^{\mathrm{a}}$ & $15.74^{\mathrm{fg}}$ & $18.67^{\mathrm{c}}$ \\
G3 & $16.18^{\mathrm{f}}$ & $17.18^{\mathrm{e}}$ & $17.51^{\mathrm{e}}$ \\
\hline
\end{tabular}

Description: The numbers followed by the same letter are not significantly different in DMRT at 5\% level. G0: without GA3, G1: 50 ppm GA3, G2: 100 ppm GA3, G3: 150 ppm GA3. N0: without shade, N1: 55\% shade, N2: 75\% shade 
Table 2. Effect of GA3 and the level of shade against the artemisinin content

\begin{tabular}{llll}
\hline & $(\%)$ & & \\
Treatment & N0 & N1 & N2 \\
\hline G0 & $0.64^{\mathrm{f}}$ & $0.79^{\text {def }}$ & $0.91^{\text {def }}$ \\
G1 & $0.72^{\text {ef }}$ & $0.96^{\text {def }}$ & $2.97^{\mathrm{b}}$ \\
G2 & $1.27^{\text {cde }}$ & $1.37^{\text {cd }}$ & $3.29^{\mathrm{b}}$ \\
G3 & $1.86^{\mathrm{c}}$ & $2.37^{\mathrm{c}}$ & $3.96^{\mathrm{a}}$ \\
\hline
\end{tabular}

Description: The numbers followed by the same letter are not significantly different in DMRT at 5\% level. G0: without GA3, G1: 50 ppm GA3, G2: 100 ppm GA3, G3: 150 ppm GA3. N0: without shade, N1: $55 \%$ shade, N2: $75 \%$ shade

Table 3. Effect of GA3 and the level of shade on height of A. аппиа

\begin{tabular}{ll}
\multicolumn{2}{c}{ A. апnua } \\
\hline G0 & $69.9^{\mathrm{a}}$ \\
\hline G1 & $77.8^{\mathrm{a}}$ \\
G2 & $84.0^{\mathrm{a}}$ \\
G3 & $84.2^{\mathrm{a}}$ \\
N0 & $87.0^{\mathrm{a}}$ \\
N1 & $73.8^{\mathrm{a}}$ \\
N2 & $76.2^{\mathrm{a}}$ \\
\hline
\end{tabular}

It can be explained that the high shade, the intensity of solar radiation that reached the surface of the plant is low, so that the leaves do not function optimally as a source of material that formed the builder. As a result, the formed-carbohydrate will be obstructed. Based on the result of Master's experiment (1998), the experiment to the wheat plants showed that the plants in shade will obstruct the production of carbohydrates. The GA3 concentration of $100 \mathrm{ppm}$ in this study was proved as best treatment on the plant fresh weight, it is assumed that at the concentration of $100 \mathrm{ppm}$ was the most appropriate concentration for its growth and development, so that when the concentration is increased or decreased, plants will suffer from stunted growth (Aftab et al., 2010). The same results have been reported for other types of medicinal plants. Utami (2000) reported that, on the Sambung Nyawa plant (Gynura sp.) the highest fresh biomass and dry biomass was obtained at high light intensity. On the katuk plant, it was reported that the higher light intensity increased the plant dry biomass (Darwati and Rosita, 1996). On the Poko plant (Mentha arvensis L.) reported that the treatment of high intensity light provided the best results on the number of leaves, fresh weight and dry weight of plants (Ning and Hartutiningsih, 2002).

\section{Dry Weight}

The result of DMRT at 5\% level, showed that, there was no significant influence on the dry weight of the plant. GA3 treatment can increase the dry weight of plant at the concentration of $100 \mathrm{ppm}$ it showed the highest dry weight and tend to decrease at higher concentrations of $150 \mathrm{ppm}$. As stated by Kusumo
(1984), for the improvement of the dry biomass, addition of GA3 will increase the height of plant, the wide of leaves and the dry weight of plants, which seems that, increase in dry weight was closely related to photosynthetic activity.

The increasing of the dry weight can be seen from the plants that received full sunlight. It is assumed by the existence of sunlight as an energy source, that the formation of dry matter relatively faster and directly accumulated and the dry weight tend to decrease because of shade treatment, it was caused by the shade which was too dense that will gave bad impact to insufficiency of light as an energy source for the metabolism of plants and finally it caused the reduction of the yield.

\section{Conclusion}

On basis of the obtained result it can be concluded that 100 ppm GA3 increase the dry weight and leaf chlorophyll content. The treatment without shade gives the best results on the height of plant, the length of roots and the total extract of yield. The treatment 150 ppm GA3 and $75 \%$ shade gave the highest result in the artemisinin content.

\section{Acknowledgement}

The authors are indebted to the Research Center of medicinal plant and traditional drug, Tawangmangu, Solo, Indonesia and Ministry of Research, Technology and Higher Education, Indonesia for supporting this research and giving an opportunity to complete this research.

\section{Funding Information}

Funding was available from Ministry of Research, Technology and Higher Education, Indonesia.

\section{Author's Contributions}

Ahmad Yunus: Coordinator to make conception and design of experiment, data analysis and discussion.

Samanhudi: Coordinator for research design, data analysis, discussion, writing of this manuscript.

Usman Siswanto: Coordinator for research work and data analysis.

Yuni Kusumodewi: Design research method, data analysis and writing of the manuscript.

\section{Ethics}

This article is original and contains unpublished material. The corresponding author confirms that all of the other authors have read and approved the manuscript and no ethical issues involved. 


\section{References}

Aftab, T., M.M.A. Khan, M. Idrees, M. dan Naeem and M. Singh et al., 2010. Stimulation of crop productivity, photosinthesis and artemisinin production in artemisia аппиа L. by triacontanol and gibberellic acid application. J. Plant Interact., 5: 273-281.

Brown, G.D., 2010. The biosynthesis of artemisinin (Qinghaosu) and the phytochemistry of artemisia annua L. (Qinghao). Molecules, 15: 7603-7698.

Darwati, I. and S.M.D.D. Rosita, 1996. Pengaruh intensitas cahaya dan ergostim terhadap pertumbuhan katuk (Sauropus androgynus Merr) prosiding simposium nasional I. tumbuhan obat dan aromatik apinmap. Hlm.

Dhingra, V., K.R. Vishwerhavar and M.N. Laksmi, 2000. Current status of artemisinin and its derivatives as antimalarial drugs. Life Sci., 66: 279-300.

Fitter, A.H. and R.K.M. Hay, 1998. Fisiologi Lingkungan Tanaman (translate by Andani dan Purbayanti). Gadjah Mada University Press.

Gardner, F.P., R.B. Pearce and R.L. Mitchell, 1985. Physiology of crop plants. (translate by Susilo). Jakarta. 1st Edn., Iowa State University Press, Ames, ISBN-10: 081381376X, pp: 327.

Gilani, A.H., S. Yaeesh, Q. Jamal and M.N. Ghayur, 2005. Hepato protective activity of aqueous methanol extract of Artemisia vulgaris. Phyto Ther. Res., 19: 170-172.

Hedden, P. and W.M. Proebsting, 1999. Genetic analysis of gibberellin biosynthesis. Plant Physiol., 119: 365-370.

Jehnsen, J.S., 2010. Effects on Artemisia annua growth with the addition of gibberellic acid, salicylic acid and methyl jasmonate in hydroponic systems. UC. Berkeley.

Judzentiene, A and J. Buzelyte, 2006. Chemical composition of essential oils of artemisia vulgaris L. (mugwort) from North Lithuania. Chemija, 17: 12-15.
Klayman, D., A.J. Lin and N. Acton, 1985. Isolation of artemisinin (Qinghaosu) from Artemisia annua growing in the United States. J. Nat. Prod., 47: 715-717.

Kusumo, S., 1984. Plant Growth Regulator. 1st Edn., CV. Yasaguna, Jakarta.

Milliken, W., 1997. Traditional anti-malarial medicine in Roraima, Brazil. Econ. Bot. 51: 212-237.

Mueller, M.S., I.B. Karhagomba, H.M. Hirt and E. Wemakor, 2000. The potential of Artemisia annua L. as a locally produced remedy for malaria in the tropics: Agricultural, chemical and clinical aspects. J. Ethnopharmacology, 73: 487-493.

Muhartini, S. and B. Kurniasih, 2000. Growth and yield of Curcurna xanthorrhiza on several light intensities and fertilizer rates. Agriculture Sci., 7: 17-21.

Mukherjee, T., 1991. Antimalarial herbal drugs- a review. Fitoterapia, 62: 197-204.

Li, Y., H. Huang and Y.L. Wu, 2006. Qinghaosu (Artemisinin)-A Fantastic Antimalarial Drug from a Traditional Chinese Medicine. In: Medicinal Chemistry of Bioactive Natural Products, Liang, X.T. and W.S. Fang (Eds.), Wiley, New York, pp: 183-256.

Liu, B., H. Wang, Z. Du, G. Li and H. Ye, 2011. Metabolic engineering of artemisinin biosynthesis in Artemisia annua L. Plant Cell Rep., 30: 689-694.

Ning, W.U. and Hartutiningsih, 2002. Productivity of Poko (Mentha arvenis L.) on several growth media and different light intensity. Procedings of the Simposium Nasional II. Medicinal and Aromatic Plant, (MAP' 02), pp: 316-320.

Rogers, D.J. and S.E. Randolp, 2000. The global spread of malaria in the future, warmer word. Science, 289 : 1697-1698.

Tang, H.Q., J. Hu, L. Yang and R.X. Tan, 2000. Terpenoids and flavonoids from artemisia spesies. Planta Med., 66: 391-393.

Utami, N.W., 2000. Produktivity of gynura procumbens (Lour)merr on growth media and level of shade. J. Agric. Sci., 6: 28-30. 